\title{
DERECHO CHILENO MIGRATORIO A LA LUZ DEL DERECHO MIGRATORIO INTERNACIONAL: ¿CEDEN LOS DERECHOS HUMANOS MÍNIMOS DE LOS EXTRANJEROS ANTE LAS PRERROGATIVAS SOBERANAS DE CONTROL MIGRATORIO?
}

\author{
CHILEAN MIGRATION LAW UNDER INTERNATIONAL MIGRATION \\ LAW: DO THE MINIMUM HUMAN RIGHTS GIVE IN TO THE \\ IMMIGRATION CONTROL SOVEREIGN PREROGATIVES?
}

\section{Cecilia Andrea Domínguez Valverde ${ }^{1}$}

\begin{abstract}
RESUMEN: La tensión del derecho migratorio internacional entre el reconocimiento del derecho de los migrantes a ser tratados de acuerdo a ciertos derechos mínimos y la facultad soberana de control migratorio se refleja en el derecho migratorio chileno. Esta tensión se traduce en la denegación de facto de los derechos humanos de los migrantes a causa de la interferencia de los mecanismos de control migratorio. Este trabajo analizará el nivel de protección que el derecho chileno procura a ciertos derechos clave para la población inmigrante, como el derecho al debido proceso, a la libertad personal, el derecho a la educación, salud y ciertos derechos laborales con el fin de contrastar su protección de jure con el efecto que producen los mecanismos de control migratorio respecto de su garantía de facto.
\end{abstract}

Palabras clave: Inmigrante, extranjero, control migratorio, derechos humanos mínimos.

ABSTRACT: International migration law's tension between the recognition of the right to be treated according certain minimum human rights and the sovereign prerogatives of migration control is reflected by the Chilean migration law. This tension results in de facto denial of immigrant minimum human rights because of the interference of migration control mechanisms. This work will analyze the protection level given by the Chilean law to an immigrant population particularly relevant rights, like the right to due process, the right to personal freedom, the right to education and health care and some labor rights, for the purpose of contrasting their de jure protection with the effect that the migration control mechanisms have in their de facto protection.

Key words: Immigrant, alien, migration control, minimum human rights.

\section{INTRODUCCIÓN}

El derecho internacional migratorio en actual construcción ${ }^{2}$, incluye tanto derechos humanos mínimos de los inmigrantes como las potestades soberanas de control migratorio.

\footnotetext{
1 Abogada Universidad de Chile, Máster en Derecho Internacional Económico Université Paris 1 PanthéonSorbonne, candidata a doctora Université Paris 1 Panthéon-Sorbonne. Dirección postal: Calle Urbieta 11 5B, 20006, España. Dirección electrónica: ceciliadom@gmail.com

2 Aunque los Estados no parecen dispuestos a crear un sistema de protección universal de los derechos de los migrantes ni a acordar criterios para la admisión, tratamiento o expulsión de los extranjeros en sus territorios, el derecho migratorio internacional se nutre del derecho internacional de los derechos humanos y de la concre-
} 
Es así como de un lado, además de los instrumentos internacionales específicamente ligados a la migración, muchas normas del derecho internacional de los derechos humanos reconocen como parte de los derechos humanos mínimos de los inmigrantes en virtud de su calidad de persona, de trabajador y sobre la base el principio igualdad y no discriminación, independientemente de su estatus migratorio ${ }^{3}$.

El contenido de esos derechos humanos mínimos, así como el alcance del principio de igualdad y no discriminación respecto de la población migrante ha sido precisado por los órganos de control de estos instrumentos internacionales, a través de sus sentencias, opiniones consultivas y otras publicaciones ${ }^{4}$.

Del otro lado, el derecho internacional reconoce a los Estados ciertas potestades soberanas de control territorial que forman parte del derecho consuetudinario internacional y se consideran el núcleo del Estado-nación moderno.

Entre estas facultades se encuentran: el control de identidad fronterizo y en territorio; la detención en frontera; la prohibición de entrada; las expulsión y restricción de la libertad de los extranjeros durante la incoación de procedimientos de sanción o a la espera de la ejecución de una sanción, entre otras.

Sin embargo, el grado de libertad con el que se ejercen las potestades de control migratorio ha sido progresivamente restringido durante el siglo XX, pasando de la más absoluta libertad, a la obligación del ejercicio individualizado del control migratorio, su motivación y la observancia de límites ligados al respeto de los derechos del extranjero.

Es así como las dos vertientes del derecho internacional migratorio presentan una relación de proporción inversa, donde el refuerzo del derecho de control migratorio perjudica la garantía de los derechos humanos mínimos de los extranjeros, y viceversa.

ción que de estos hacen los órganos de protección. En este sentido ver Pérez GonZÁlez (2012) p. 3. Para más profundización ver, Pérez-Prat Durban (2007) pp. 143-144 y Rigaux (2000) p. 693.

${ }^{3}$ Entre estos instrumentos se cuentan la Declaración Universal de Derechos Humanos de 1948 (en adelante DUDH); Pacto Internacional de Derechos Civiles y Políticos de 1963 (en adelante PIDCP), Pacto Internacional de Derechos Económicos, Sociales y Culturales de 1966 (en adelante PIDESC); la Convención sobre el Estatuto de Refugiados de 28 de julio de 1951; Convención Internacional sobre la Eliminación de todas las formas de discriminación racial de 1965; la Convención contra la tortura y otros tratos o penas crueles inhumanas o degradantes de 1984 (en adelante CAT); la Convención Internacional sobre la protección de los derechos de todos los trabajadores migratorios y sus familiares, de 1990 (en adelante CIPDTMYF); Convenio O.I.T. No. 97 sobre los Trabajadores Migrantes (revisado) de 1949; Convenio No. 143 sobre los Trabajadores Migrantes (disposiciones complementarias) de 1975; Convenio 105 para la abolición del trabajo forzoso 1957; Convenio 111 relativo a la discriminación en materia de empleo y ocupación de 1958; Recomendación 86 sobre los trabajadores migrantes 1949, Recomendación 151 sobre los trabajadores migrantes 1975; Recomendación 167 sobre la conservación de los derechos en materia de seguridad social 1983; Convención Americana sobre Derechos Humanos de 1969 (en adelante CADH); Declaración Americana de los derechos y deberes del hombre de 1948 (en adelante DADH), entre otros.

${ }^{4}$ En este sentido se han pronunciado diferentes órganos de control del sistema de protección del derecho internacional de derechos humanos, como el Comité de Derechos Humanos, el Comité para la Eliminación de la Discriminación Racial; Comité sobre los Derechos Económicos, Sociales y Culturales; Comité de protección de los Derechos de los trabajadores migrantes y de sus familiares; la Corte Interamericana de Derechos Humanos (en adelante Corte Interamericana) y la Comisión Interamericana de Derechos Humanos, entre otros. 
En esta interacción parece de facto triunfar el derecho estatal de control migratorio, estén o no reconocidos los derechos mínimos de los migrantes de jure ${ }^{5}$. Ello, pues a menudo, el mero ejercicio de un derecho mínimo acarrea la revisión del estatus migratorio -trayendo consigo la incoación de un procedimiento sancionatorio- o porque las exigencias adicionales de las que es objeto esta población, por ejemplo en materia laboral, hace imposible probar la existencia de un contrato de trabajo, incluso si el extranjero se encuentra en situación administrativa regular.

El reconocimiento de esta relación en el seno del derecho internacional migratorio, exige integrar el análisis de los dispositivos de control migratorio en la revisión del nivel de reconocimiento y protección de los derechos de los inmigrantes.

A continuación, se analizará sucintamente el derecho internacional migratorio, dejando ver la relación entre su vertiente garantista y aquella de control, en los términos en que la ha concebido la Corte Interamericana de derechos humanos.

Enseguida, se considerará esta tensión estructural en la regulación nacional, poniendo el acento en la diversidad de fuentes y de jerarquía normativa, así como en los problemas que implican la falta de armonía, conocimiento y promoción de las normas migratorias.

En tercer lugar, se revisará la regulación migratoria chilena vigente a la luz de la regulación internacional jurídicamente vinculante para Chile con el fin estimar el nivel de reconocimiento, respeto y garantía de los derechos al debido proceso, a la libertad personal, a la salud, a la educación y los derechos de los trabajadores migrantes.

Finalmente, se concluye proponiendo ciertos cambios regulatorios que cimenten el camino hacia un nuevo equilibrio que permita tanto el efectivo ejercicio de los derechos humanos mínimos, como el despliegue de facultades razonables de control migratorio.

\section{CONTROL MIGRATORIO VS. DERECHOS HUMANOS MÍNIMOS EN EL DERECHO INTERNACIONAL}

Si bien el derecho internacional migratorio contiene las dos vertientes descritas, no propone una articulación precisa entre estas, sino que tolera el despliegue paralelo y espontáneo de las mismas, de manera que el desarrollo de la una limita de jure o de facto el desarrollo de la otra, y viceversa.

En cuanto al contenido de los derechos humanos mínimos, se puede afirmar que estos se desarrollan a partir del reconocimiento del derecho a emigrar ${ }^{6}$ y a retornar al país de origen o residencia ${ }^{7}$ y aunque no constituyen un derecho a inmigrar propiamente tal, constituyen ciertas exigencias mínimas de trato respecto de la población extranjera que se presenta en frontera o que se halle en el territorio de un Estado.

\footnotetext{
5 Kamto (2007) párrafos 2 y 7.

6 Aunque el artículo 13.1 de la DUDH parece establecer un derecho a emigrar y uno a inmigrar en el derecho a la libre circulación y a elegir la residencia en el territorio de un Estado, el artículo 12 del PIDCP restringe el derecho a inmigrar a las personas que se hallen legalmente en el territorio de un Estado.

7 Artículos 13.2 DUDH y 12.4 PIDCP. Ver también Comité de Derechos Humanos (1999) y Comité de Derechos Humanos (2001).
} 
Es así como la prerrogativa graciable de la denegación a la entrada del Estado es limitada por el derecho internacional en ciertos casos.

De esta forma, la prerrogativa soberana de expulsión se suspende cuando el extranjero solicite refugio, estando el Estado obligado a iniciar el debido acompañamiento del proceso para el reconocimiento del derecho de asilo ${ }^{8}$.

Además, la adopción de una decisión de expulsión está limitada por su propia ley y siempre que la persona extranjera no corra peligro en su vida o integridad en caso de ser devuelta a su país de origen o a un tercer país?.

Por otro lado, aunque el Estado no está obligado a regularizar la situación administrativa de los extranjeros que se encuentran ilegalmente en su territorio ${ }^{10}$, el derecho internacional le obliga a tratarles de acuerdo a sus derechos mínimos.

Sobre ese punto se ha pronunciado la Corte Interamericana en ciertas opiniones consultivas y decisiones judiciales ${ }^{11}$, donde afirma que dichos derechos humanos provienen de la calidad de persona del inmigrante ${ }^{12}$, de la aplicación del principio de igualdad y no discriminación y de su calidad de trabajador.

\footnotetext{
${ }^{8}$ Este principio se encuentra recogido en el artículo 3 del CAT y exige a los Estados la organización de una estructura interna de protección gracias a mecanismos administrativos y judiciales acordes al debido proceso. Ver, Comisión Interamericana de Derechos Humanos (2008).

9 A nivel regional el artículo $22 \mathrm{CADH}$ restringe la acción estatal, exigiendo que la limitación del derecho a la libre circulación se realice en virtud de una ley cuando sea indispensable para proteger la seguridad nacional, la seguridad o el orden públicos, la moral o la salud públicas o los derechos y libertades de los demás o en un ámbito geográfico cuando lo motiven razones de interés público. Además, prohíbe la expulsión de nacionales o la denegación a la entrada de los mismos, exige que la expulsión de los no nacionales se realice en virtud de una decisión adoptada conforme a la ley y de forma individual, siempre que su vida o integridad física no se encuentren en peligro.

${ }^{10}$ La obligación de trato no discriminatorio y acorde a los derechos humanos comienza desde que el extranjero se encuentra bajo la jurisdicción del Estado acuerdo al artículo 2.1 PIDCP, artículo 7 Convención contra todas las formas de discriminación contra la mujer y el artículo 1.1 CADH. Dicha jurisdicción sobrepasa los límites territoriales del Estado para aplicarse a toda persona bajo la autoridad y el control efectivo de las autoridades de un Estado o de personas que actúen en su nombre, incluyendo las zonas de espera o internacionales. Sobre este punto ver, Comité de Derechos Humanos (2004) párrafos. 10-11; Delia López Burgos v. Uruguay (1979); Celiberti de Casariego v. Uruguay (1981); Cour InTernationale De Justice (2004) párr. 109; Víctor Saldaño v. Argentina (1999) párr. 17; Comité Haitiano de Derechos Humanos v. Estados Unidos (1997); Coard y otros v. Estados Unidos (1999) párr. 37; Corte Interamericana de Derechos Humanos (2002).

11 Torres-Marenco (2011) pp. 41-76.

12 El artículo 24 de la CIPDTMYF reitera la personalidad de los trabajadores migratorios, consagrando su derecho a ser reconocidos legalmente como tales. Ver Corte Interamericana de Derechos Humanos (2003) párr. 72. Entre estos derechos se cuentan la libertad de expresión, opinión, conciencia, el derecho de reunión y asociación, el derecho al debido proceso, el derecho a la vida e integridad física, el derecho a la vida privada y familiar, entre otros que se desarrollarán a continuación. En el Comentario General No. 15 del Comité de Derechos Humanos, destaca que el disfrute de los derechos reconocidos por el Pacto no se limita a los ciudadanos de los Estados Partes, sino que alcanza a todos los individuos, independientemente de su nacionalidad o condición de apátridas y demás personas que estén en el territorio o bajo la jurisdicción del Estado Parte. Ver Comité de Derechos Humanos (1986). Estos derechos se encuentra consagrados también en los artículos 12, 13 y 14 de la CIPDTMYF.
} 
La obligación de respetar y garantizar los derechos humanos se encuentra plasmada en varios instrumentos internacionales ${ }^{13}$ y no solo obliga a reconocer formalmente dichos derechos, sino que a hacerlos efectivos en virtud del principio de l'effet utile ${ }^{14}$.

Asimismo, el respeto del principio de igualdad y no discriminación ${ }^{15}$, que se compone por los elementos no discriminación, igualdad ante la ley y la igual protección de la ley ${ }^{16}$, no solo implica la abstención por parte del Estado de realizar acciones que produzcan situaciones de discriminación de jure, sino que también de facto.

La Corte Interamericana precisa que esta obligación alcanza a la totalidad de los derechos contemplados por la CADH y el PIDCP, a todos los Estados, acarrea obligaciones erga omnes ${ }^{17}$ y debe respetarse con independencia de la situación administrativa del extranjero.

En lo que se refiere a los derechos laborales, la Corte afirma que estos provienen de su condición de trabajador, entendida esta en su sentido más amplio, es decir, del hecho que se vaya a realizar, se realice o se haya realizado una actividad remunerada ${ }^{18}$.

Dicha condición trae consigo todos los derechos inherentes a ella, pues el derecho del trabajo internacional o doméstico, es un ordenamiento tutelar que regula los derechos y obligaciones del empleado y del empleador, con independencia de cualquier otra consideración, como la condición migratoria ${ }^{19}$.

La Corte Interamericana precisa que aunque el Estado y los particulares pueden abstenerse a establecer una relación laboral con los inmigrantes indocumentados, una vez que les contratan para trabajar, estos se convierten en titulares de los derechos de los trabajadores ${ }^{20}$.

La obligación de respeto y garantía de los derechos laborales de los inmigrantes tiene un efecto directo en todo tipo de relación laboral y se traduce muchas veces en la acción estatal, inclusive cuando el Estado no forma parte de la relación de trabajo, pues es él quien a través de su sistema de judicial o de seguridad social va a reconocer y hacer cumplir estos derechos y va a impedir que se creen o mantengan situaciones de discriminación por parte de terceros ${ }^{21}$.

Ahora bien, el reconocimiento y garantía de los derechos mínimos de los inmigrantes no implica la negación de las facultades soberanas de control migratorio. De hecho, la Corte Interamericana define las políticas migratorias como "todo acto medida u omisión

${ }^{13}$ Artículos 1 y 2 de la CADH, artículo 1 del Protocolo Adicional a la CADH en Materia de Derechos Económicos, Sociales y Culturales, artículo 55 c) de la Carta de las Naciones Unidas, el Preámbulo de la DUDH, artículo 2.1 y 2.2 del PIDCP, el artículo 2.2 del PIDESC, artículo 7 de la CIPDTMYF y el Preámbulo de la Convención Internacional sobre la Eliminación de todas las formas de Discriminación Racial.

${ }^{14}$ Artículo $2 \mathrm{CADH}$, confirmado por Corte Interamericana de Derechos Humanos (2003) párr. 77 y reiterado por La Cantuta vs. Perú (2006); Cantos v. Argentina (2002) párr. 59; Hilaire, Constantine y Benjamín y otros v. Trinidad y Tobago (2002) párr. 213. En el mismo sentido "Cinco Pensionistas" v. Perú (2003) párr. 163.

15 Consagrado en los artículos 3.I y 17 de la Carta de la OEA, el artículo 24 de la CADH, el artículo II de la

DADH; el artículo 26 del PIDCP y el artículo 2.1 de la DUDH.

16 Corte Interamericana de Derechos Humanos (2003) párr. 84.

17 Corte Interamericana de Derechos Humanos (2003) párrafos 84 y 109.

18 Preámbulo CIPDTMYF.

19 Corte Interamericana de Derechos Humanos (2003) párrafos 133, 134.

20 Corte Interamericana de Derechos Humanos (2003) párrafos 136- 149.

${ }^{21}$ Corte Interamericana de Derechos Humanos (2003) párrafos 150- 152. 
institucional (...) que versa sobre la entrada, salida o permanencia de la población nacional o extrajera dentro de su territorio" ${ }^{22}$, incorporando las dos vertientes del derecho internacional migratorio ${ }^{23}$.

Es más, la Corte Interamericana reconoce la facultad estatal de iniciar acciones contra las personas que no respeten el orden jurídico del Estado, siempre que dichas medidas respeten y garanticen los derechos humanos, en particular el derecho al debido proceso $^{24}$.

Al respecto, insta a todos los Estados a revisar y modificar sus políticas migratorias con el fin de erradicar todo elemento que sea incompatible con sus obligaciones en virtud de los instrumentos internacionales de derechos humanos.

De esta manera, la Corte Interamericana da cuenta de la tensión estructural del derecho internacional cuando se refiere a los inmigrantes, pues aunque el Estado conserva su prerrogativa de control migratorio y del mercado laboral a través del otorgamiento de permisos de trabajo, esta prerrogativa se ve de jure limitada por la protección de los derechos humanos mínimos, la aplicación del principio de igualdad y no discriminación y la protección de los derechos que provengan de su condición de trabajador.

\section{CONTROL MIGRATORIO VS. DERECHOS HUMANOS MÍNIMOS EN EL DERECHO MIGRATORIO CHILENO}

Aunque la inmigración representa un porcentaje relativamente pequeño de la población total de Chile ${ }^{25}$, sobrepasando tímidamente el 2\%, su progresivo aumento a partir de la década de 1990 -pasando de 184.464 personas en $2002^{26}$ a 398.251 en $2013^{27}$-, hace cada vez más pertinente el análisis de la normativa que regula a la población extranjera.

El derecho migratorio chileno se nutre de fuentes normativas de variada jerarquía. De esta forma, aunque la regulación específica de la extranjería se compone por el Decreto Ley 1094 de $1975^{28}$ (en adelante Decreto Ley de Extranjería) y su Reglamento ${ }^{29}$ (en adelante Reglamento de Extranjería), variados oficios circulares, decretos, y resoluciones completan la normativa en esta materia ${ }^{30}$.

22 Corte Interamericana de Derechos Humanos (2003) párr. 163.

23 Corte Interamericana de Derechos Humanos (2003) párr. 169.

24 Corte Interamericana de Derechos Humanos (2003) párr. 119.

25 La inmigración espontánea apreciable a partir de la década de 1990 es un desafío nuevo para el derecho nacional. Ello, pues en los periodos precedentes los flujos migratorios habían sido promovidos -con y sin éxitodesde el gobierno central, propendiendo a la llegada de población eminentemente blanca, europea y cristiana. Incluso la legislación actualmente vigente, se crea con el fin de responder a la migración contraria al régimen -considerada peligrosa o de corte "terrorista"- dentro de un contexto de escasa inmigración.

26 Organización Internacional de Migraciones (2012) p. 19

27 Noticias Cámara de Diputados de Chile, "Este sábado realizan seminario sobre migraciones en congreso nacional en Santiago con testimonios de inmigrantes”, 10 de octubre 2014, disponible en http://www.camara.cl/prensa/ noticias_detalle.aspx?prmid=118125

28 Decreto Ley 1094, de 19 de julio de 1975, Normas sobre Extranjeros en Chile.

29 Decreto Supremo 597, de 24 de noviembre de 1984, Reglamento de Extranjería.

30 Este artículo se referirá únicamente a la regulación general de la inmigración económica, excluyéndose la regulación en materia de refugio y los acuerdos regionales que instituyen un tratamiento diferenciado a personas de ciertas nacionalidades, como es el caso del acuerdo MERCOSUR, por ejemplo. 
Empero, este conglomerado de normas no constituye una política migratoria coherente, sino que más bien una regulación improvisada, resultado de la inercia jurídica e institucional ${ }^{31}$. Autores más críticos afirman la existencia de una verdadera política migratoria de expulsión masiva ${ }^{32}$.

En efecto, no existe ningún plan nacional ${ }^{33}$ que considere el tipo de inmigración que se recibe, las necesidades que el mercado de trabajo nacional presenta, la estructura demográfica de la población nacional, las necesidades de la población migrante o el marco regional y global en el que se enmarca el fenómeno migratorio chileno ${ }^{34}$.

Esta falta de visión de conjunto explica en parte la espontaneidad de la llegada de la inmigración en Chile y la falta de armonía en la regulación, que se disgrega en múltiples instrumentos que no son debidamente dados a conocer, lo que favorece situaciones de irregularidad migratoria y la vulneración de los derechos humanos de los inmigrantes.

Ahora bien, si utilizamos la estructura de la que se dio cuenta precedentemente respecto del derecho migratorio internacional para comprender la regulación nacional de extranjería, se confirma la existencia de dos tipos de normas.

De un lado, se pueden encontrar las normas de control migratorio, que se condensan principalmente en el Decreto Ley de Extranjería y su Reglamento. Estos instrumentos disponen diversos mecanismos de control de la población extranjera, tanto al momento de solicitar una visación en el extranjero, como en el momento del ingreso y dentro del territorio nacional. Estos mecanismos de control son ejercidos tanto por las policías y los funcionarios públicos en general, como por particulares sobre los que recaen ciertas obligaciones de control.

Pese a que el tipo control migratorio presente en el Decreto Ley de Extranjería se ha atribuido al carácter autoritario del gobierno en el que fue adoptado, muchos de los dispositivos de control migratorio contenidos en esta regulación guardan similitudes con los dispositivos de lucha antiterrorista y contra la criminalidad internacional que han sido insertados por los gobiernos occidentales a partir de la década de 1990 y en especial, luego de los atentados terroristas del 11 de septiembre de $2001^{35}$.

31 El Instructivo Presidencial No 009 de 2008 adoptado por la Presidenta Michelle Bachelet es un esfuerzo en la dirección correcta, pese a que no se tradujo en ningún cambio estructural de la regulación migratoria chilena. Ver Presidente de la República (2008).

32 Oficina Especializada de Derechos Humanos de la Corporación de Asistencia Judicial (2013): "Solicitud al Pleno de la Corte Supma, por grave situación que afecta a los extranjeros en Chile” en Centro DemoCracia y Comunidad Ciudadano Global et al. (2013) pp. 81-82. De acuerdo a la opinión de los abogados Caucoto y Möller, ello se refleja en la realización expulsiones pese a la existencia de una gestión administrativa pendiente; la expulsión de personas reconocidas como refugiadas y la denegación masiva de recursos de reconsideración respecto de actos administrativos del Ministerio del Interior.

33 Las modificaciones legislativas aprobadas durante los gobiernos de Frei y de Bachelet no han logrado cambiar el tenor policial del Decreto Ley de Extranjería, mientras que las propuestas de modificación integral de Aylwin y Piñera nunca llegaron a aprobarse.

34 Sobre el marco regional y global de la migración ver Corte InTeramericana de Derechos Humanos (2003) párrafos 115-117 y Asamblea General de Naciones Unidas (2000b).

35 En este sentido ver, Ley Orgánica 4/2000, de 11 de enero, sobre derechos y libertades de los extranjeros en España y su integración social, BOE número 10 de 12 de enero 2000 y la Immigration and Nationality Act de 1952 en el 8 U.S. Code 1158. 
Del otro lado, las normas que garantizan los derechos de las personas inmigrantes se encuentran en la Constitución Política de la República, así como en el derecho internacional de los derechos humanos presente en las tratados internacionales de derechos humanos ratificados por Chile, en particular, la Convención Internacional sobre la protección de los derechos de todos los trabajadores migratorios y sus familiares. Ni el Decreto Ley Extranjería ni su Reglamento contienen norma alguna referida a los derechos de los inmigrantes.

De esta forma, el artículo $1^{\circ}$ de la Constitución Política de la República establece "las personas nacen libres e iguales en dignidad y derechos", sin distinguir entre nacionales y extranjeros ni entregar a la ley la regulación de los derechos de estos últimos.

Luego, reafirma la importancia de esos derechos en su artículo $5^{\circ}$ inciso $2^{\circ}$ que precisa que "la soberanía reconoce como limitación el respeto a los derechos esenciales que emanan de la naturaleza humana" y añade "Es deber de los órganos del Estado respetar y promover tales derechos garantizados por esta Constitución, así como por los tratados internacionales ratificados por Chile y que se encuentren vigentes”. Es así como se integran al derecho nacional las normas internacionales de derechos humanos respeto de las personas inmigrantes.

Además, el artículo 19 de la Constitución Política de la República consagra en sus numerales 2 y 3 el principio de igualdad y no discriminación.

Como se verá a continuación en el análisis del nivel de protección de algunos de los derechos mínimos de los inmigrantes, los diversos mecanismos de control migratorio presentes en la regulación chilena suponen un inacabado y poco efectivo sistema de protección de los derechos de los extranjeros en el derecho migratorio nacional.

\section{A. Derecho de los migrantes al Debido proceso}

A nivel constitucional, este derecho se encuentra consagrado en el artículo 19 número 3 de la Carta Magna, donde se consagra el derecho de igual protección de la ley en el ejercicio de los derechos, la defensa jurídica, la debida intervención del letrado y asistencia jurídica gratuita y el derecho a que la jurisdicción se funde en un proceso previo legalmente tramitado que respete las garantías de un procedimiento y una investigación racionales y justos.

Estos derechos son desarrollados por algunos órganos de control del derecho internacional. De esta forma, la Corte Interamericana hace extensivo el derecho al debido proceso a toda persona, independientemente de su estatus migratorio ${ }^{36}$ y precisa que este derecho está compuesto por el conjunto de requisitos que deben observarse en las instancias procesales a efectos de garantizar el derecho a la defensa ante cualquier acto del Estado, se trate de un proceso administrativo sancionatorio o jurisdiccional ${ }^{37}$, incluyendo los procedimientos de expulsión ${ }^{38}$.

\footnotetext{
36 Ver Corte Interamericana de Derechos Humanos (1999), donde se afirma que para que exista "debido proceso legal" es preciso que un justiciable pueda hacer valer sus derechos y defender sus intereses en forma efectiva y en condiciones de igualdad procesal con otros justiciables.

37 Artículo 8.1 de la CADH.

38 Corte Interamericana de Derechos Humanos (2003) párrafos 124-127; Comisión Interamericana de Derechos Humanos (2002) párrafos 398-403.
} 
En particular, la Corte Interamericana ha afirmado que se aplican a los procedimientos de expulsión el derecho a una audiencia pública ${ }^{39}$; el derecho a ejercer adecuada y oportunamente el derecho a la defensa ${ }^{40}$; el derecho a ser asistido por un abogado y a la asistencia jurídica gratuita ${ }^{41}$; el derecho a un tiempo suficiente para presentar descargos ${ }^{42}$; el derecho a un tiempo razonable para preparar y formalizar una respuesta y buscar y alegar evidencia contradictoria ${ }^{43}$; el derecho a ser informado con anticipación de las razones de la expulsión; el derecho a apelar la decisión ante un juez o tribunal superior; el derecho a la asistencia consular cuando la persona migrante está privada de la libertad ${ }^{44}$ y el derecho a la notificación.

La Convención Internacional sobre los derechos de todos los trabajadores migratorios y sus familiares reitera estos derechos y adiciona el derecho a tener una oportunidad razonable, antes o después de la partida, para arreglar lo concerniente al pago de los salarios y otras prestaciones que se le adeuden ${ }^{45}$.

Si bien, se acepta que un número de derechos puede ser afectado por la expulsión, cuando el goce de los derechos a la vida familiar, vida privada o el derecho de religión o credo se ve perjudicado por la decisión de expulsión, se exige que esta esté prescrita por la ley de manera precisa, sea necesaria en una sociedad democrática y proporcional al objetivo legítimo que persigue ${ }^{46}$.

En el examen de proporcionalidad debe establecerse, entonces, la existencia de razones suficientes y relevantes que justifican la medida de expulsión, sin que ninguna otra medida menos restrictiva sea realizable y ante la existencia de salvaguardas suficientes contra el abuso en el marco de un procedimiento justo ${ }^{47}$.

La regulación nacional de extranjería no parece cumplir con las exigencias del debido proceso, tal como se establecen en la Constitución Política, ni menos aún con los estándares de derecho internacional.

Ello, porque la medida expulsión o denegación a la entrada, que puede ser impuesta en frontera, al momento del otorgamiento, prórroga o renovación de una visación o como resultado de un proceso sancionatorio fundado en la infracción de las normas migratorias, raramente se basa en procedimientos o en el ejercicio de facultades que observan el debido proceso, sea porque la ley no determina de manera precisa las hipótesis que conllevan a la expulsión, porque no se realiza una ponderación de los otros derechos que pueden verse afectados por la expulsión en el caso concreto o porque el procedimiento no contempla ni

\footnotetext{
39 Comisión Interamericana de Derechos Humanos (2002) párr. 403; Riebe Star y otros vs. México (1999) párr. 71.

40 Comisión Interamericana de Derechos Humanos (2002) párr. 403.

41 Vélez Loor vs. Panamá (2010) párr. 146; Comisión Interamericana de Derechos Humanos (2002) párr. 403; Riebe Star y otros vs. México (1999) párr. 71.

42 Riebe Star y otros vs. México (1999).

43 Comisión Interamericana de Derechos Humanos (2002) párr. 403; Riebe Star y otros vs. México (1999) párr. 71.

44 Corte Interamericana de Derechos Humanos (1999).

45 Ver artículos 18, 22 y 23 de la CIDTMYF.

46 Artículos 17 y 23 PIDCP; Artículo $11 \mathrm{CADH}$.

47 Rubin Byahuranga v. Denmark (2004) párr. 9.8.
} 
la audiencia del afectado o su representante, dificulta la asesoría jurídica o deniega de jure o de facto el derecho al recurso.

En primer lugar, respecto del ingreso del extranjero al territorio nacional, el artículo 2 del Reglamento de Extranjería exige que se realice siempre que este cumpla con los requisitos legales y no esté sujeto a una prohibición.

La falta de determinación normativa de las prohibiciones que redundan en la denegación a la entrada es fuente de arbitrariedad por parte de la administración, en particular, debido a la indeterminación de sus causales, la falta de recursos especiales para revocarlas, la recurrente omisión de su duración ${ }^{48}$ y la inexistencia de procedimientos de readmisión. Además, estas prohibiciones se pueden adoptar ex ante o ad hoc.

En el primer caso, la prohibición se adopta por el Ministerio del Interior por Decreto Supremo antes de que el extranjero se presente en el puesto fronterizo, ya sea, de oficio o a instancias de la Dirección General de Investigaciones y los organismos de seguridad nacional, cuando los antecedentes indiquen que el regreso del extranjero a Chile "es inconveniente" o este "no sea merecedor de ingresar al territorio nacional" ${ }^{4}$. Como se observa, las hipótesis que dan lugar a la prohibición carecen de determinación y funcionan como una especie de cajón de sastre, donde casi todo extranjero puede entrar.

La prohibiciones ad hoc, son adoptadas por el funcionario de frontera si considera que el extranjero se encuentra en alguna de las situaciones prescritas en los artículos 26 y 27 del Reglamento de Extranjería, en virtud de antecedentes de fuente propia o canalizada a través de la INTERPOL. Aunque dichas prohibiciones deben ser confirmadas por una resolución o decreto del Ministerio del Interior, su dictación formal será muy posterior a la denegación de entrada, haciendo aparentes los recursos en su contra.

Adicionalmente, las hipótesis que permiten su adopción son extremo subjetivas e indeterminadas, incluyendo causales tan abiertas como "los que realicen actos contrarios a los intereses de Chile o constituyan un peligro para el Estado", "los que ejecuten actos contrarios a la moral o a las buenas costumbres" o los que "carezcan de recursos que les permitan vivir en Chile sin constituir una carga social”, entre otras ${ }^{50}$.

Por otra parte, el artículo 27 del Reglamento de Extranjería establece una facultad aún más discrecional, que autoriza al funcionario de frontera a denegar el ingreso de los extranjeros condenados o procesados por delitos comunes calificados de simples delitos, los expulsados por otro país o los menores de 18 años que viajen solos sin autorización, entre otras causales.

Es importante notar que el establecimiento de una regulación tan favorable a la discrecionalidad del funcionario de frontera permite actuaciones discriminatorias en la más absoluta impunidad, de las que no se lleva registro alguno.

En segundo lugar, respecto de quienes quieran ingresar como residentes, el artículo 15 del Reglamento de Extranjería concede al Servicio Exterior la competencia para verificar el cumplimiento de los requisitos legales y la ausencia de prohibiciones. No obstante, el

\footnotetext{
48 Artículo 29 Reglamento de Extranjería.

49 Artículo 28 Reglamento de Extranjería

50 Artículos 26 y 27 del Reglamento de Extranjería.
} 
listado de requisitos contenido en dicho artículo es meramente enunciativo, por lo que el Servicio Exterior puede denegar una visación por razones carentes de asidero legal.

De la misma manera, el artículo 13 del Decreto Ley de Extranjería concede amplias prerrogativas al Ministerio del Interior respecto de la concesión de visaciones, prórrogas o la permanencia definitiva en el territorio nacional.

Es así como, el Ministerio del Interior debe atender -entre otras consideraciones- a la conveniencia o utilidad que reporte al país la concesión de la visación, previa atención del informe de la Dirección General de la Policía de Investigaciones, sin que la ley entregue directrices sobre qué constituye dicha conveniencia o utilidad o cuál es el contenido o peso del informe policial respeto de la decisión final.

Aunque, los recursos de reposición y jerárquico serían aplicables a estas decisiones en virtud de la Ley de Procedimiento Administrativo ${ }^{51}$, el amplio margen de maniobra concedido por el artículo 13 del Decreto Ley de Extranjería, hace difícil vislumbrar alguna decisión revocatoria.

Además, la indeterminación descrita a propósito de las prohibiciones tiene cabida en la concesión de visaciones, prórrogas de turismo, prórrogas de visaciones y la concesión de la permanencia definitiva, pues sus hipótesis deben ser consideradas al momento de conceder o denegar una visación ${ }^{52}$. Las mismas hipótesis se prevén en la institución de la revocación ${ }^{53}$.

En tercer lugar, los procedimientos sancionatorios previstos por el Decreto Ley de Extranjería y su Reglamento no parecen respetar tampoco los estándares mínimos del debido proceso, en particular en lo que se refiere en el procedimiento administrativo sancionatorio que prevé la medida de expulsión.

La normativa de extranjería prevé ciertas infracciones que conllevan específicamente la sanción de expulsión. Sin embargo, estas hipótesis adolecen de la característica falta de precisión propia del control migratorio nacional ${ }^{54}$.

\footnotetext{
51 Artículo 15 de la Ley 19.880 de 2003, sobre procedimiento administrativo.

52 Artículo 64 Decreto Ley de Extranjería: "Pueden rechazarse las solicitudes que presenten los siguientes peticionarios (1) Los condenados en Chile por crimen o simple delito (...) (3) Los que durante su residencia en el territorio nacional realicen actos que puedan significar molestias para algún país con el cual Chile mantenga relaciones diplomáticas o para sus gobernantes; (5) Los que infrinjan las prohibiciones o no cumplan las obligaciones que les impone este decreto ley y su reglamento; (6) Los que no observen las normas, sobre plazos establecidos en este decreto ley y su reglamento, para impetrar el respectivo beneficio; (7) Los residentes sujetos a contrato que por su culpa dieren lugar a la terminación del respectivo contrato de trabajo, y (8) Los que no cumplan con sus obligaciones tributarias. Asimismo, podrán rechazarse las peticiones por razones de conveniencia o utilidad nacionales".

53 Decreto Ley de Extranjería, artículos 66 y 67, Reglamento de Extranjería artículos 140 y 141.

54 Artículo 17 Decreto Ley de Extranjería. Estos incluyen: la propagación de doctrinas que tiendan a destruir o alterar por la violencia el orden social o sistema de gobierno; pertenezcan a sindicatos o tengan reputación de agitadores o activistas o en general; los ejecutores de hechos calificados como delitos contra la seguridad exterior, soberanía nacional, seguridad interior o peligrosos para el Estado; el Comercio o tráfico ilícito de drogas, armas, contrabando, trata de personas y en general actos contrarios a la moral y las buenas costumbres y; los que no tengan profesión u oficio o carezcan de recursos que les permitan vivir en Chile que puedan constituir una carga social.
} 
Asimismo, se prevé el allanamiento como medida tendiente a hacer efectiva la sanción de expulsión ${ }^{55}$. Empero, esta medida no observa los requisitos del sistema procesal penal $^{56}$, sino que es el resultado de un decreto del Intendente Regional o el Gobernador Provincial.

Además, la expulsión puede ser impuesta ya sea, por resolución exenta del Intendente Regional en el caso de los extranjeros con permiso de turismo, válido o vencido o por decreto supremo fundado del Ministerio del Interior, en los demás $\operatorname{casos}^{57}$, sin que se justifique esta distinción que luego redunda en la denegación de recursos especiales, como se verá a continuación.

Decretada la expulsión, debe ser notificada personalmente para su ejecución ${ }^{58}$. Pese a ello, existen muchos casos en que la notificación se realiza de oídas o en el momento de la detención, inhabilitando al afectado para procurarse la asesoría jurídica necesaria ${ }^{59}$.

Adicionalmente, el Decreto Ley de Extranjería limita el recurso especial de reclamación ante la Corte Suprema a las expulsiones decretadas por Decreto Supremo, sin que ninguna razón justifique la denegación del recurso de reclamación respecto del resto de medidas de expulsión.

Más aún, el mismo recurso de reclamación es una vía restrictiva, pues debe interponerse en el brevísimo plazo de 24 horas, sin que recaiga sobre Policía de Investigaciones ninguna obligación de informar sobre los recursos disponibles ${ }^{60}$ y solo puede ser interpuesto por el interesado o su familia, estando el primero privado de libertad durante la tramitación del recurso ${ }^{61}$ y la familia generalmente fuera del territorio nacional.

Por lo demás, la Corte Suprema realiza un control sumamente formalista del acto de expulsión, reconociendo las facultades amplísimas al Ministerio del Interior, sin pronunciarse sobre el fondo de la decisión que motiva la orden de expulsión ni realizar la ponderación del resto de los derechos del extranjero en juego ${ }^{62}$, tal como exige el derecho internacional ${ }^{63}$.

\footnotetext{
55 Artículo 86 del Decreto Ley de Extranjería y 170 del Reglamento de Extranjería.

56 Artículo 266 del Código Procesal Penal.

57 Artículo 84 Decreto Ley de Extranjería y 167 del Reglamento de Extranjería.

58 Artículo 90 Decreto Ley de Extranjería

59 Así lo afirman los abogados Möller y Caucoto. Oficina Especializada de Derechos Humanos de la Corporación de Asistencia Judicial (2013): "Solicitud al Pleno de la Corte Supma. por grave situación que afecta a los extranjeros en Chile” en Centro Democracia y Comunidad Ciudadano Global et al. (2013) p. 61 Aunque el derecho a la asistencia jurídica gratuita se aplica a chilenos y extranjeros sin distinción siempre que no posean suficientes recursos de acuerdo a la Ley 17995 de 1981, existe dificultad en el acceso a esta asistencia por parte de la población migrante en situación administrativa irregular, pues la Corporación exige una cédula de identidad chilena vigente para procurar la asistencia.

60 Artículo 90 Decreto Ley de Extranjería y artículo 175 del Reglamento de Extranjería.

${ }^{61}$ Artículo 89 Decreto Ley de Extranjería.

62 Son ejemplo de este análisis formalista las Sentencias de inadmisibilidad de la Corte de Apelaciones de Santiago, Rol de Ingreso 8755-2012 y 8754-2012, Oficina Especializada de Derechos Humanos de la Corporación de Asistencia Judicial (2013): "Solicitud al Pleno de la Corte Supma. por grave situación que afecta a los extranjeros en Chile” en Centro Democracia y Comunidad Ciudadano Global et al. (2013) pp. 66 y 75.

63 Últimamente se ven avances en el control de los méritos. Ver Nestares Alcántara, Helvi y otro con Departamento de Extranjería y Migración del Ministerio del Interior (2009).
} 
Por otro lado, la jurisprudencia de las Cortes de Apelaciones tiende a no acoger las acciones de protección y de amparo interpuestas respecto de los actos de expulsión. Ello, sobre la base de la existencia de una vía administrativa para reclamar en el caso de las resoluciones exentas o de la existencia un recurso especial, en el caso de los decretos supre$\operatorname{mos}^{64}$. Esta jurisprudencia bastante llamativa, si consideramos la regulación de estas acciones constitucionales no exige el agotamiento de los recursos disponibles.

Como se observa del análisis precedentemente expuesto, la falta de determinación normativa de la regulación migratoria chilena en regulación del control migratorio, permite a las autoridades resolver los dilemas migratorios en base a la mera discreción y sin contar con el mérito de estándares objetivos. Ello, aparejado a la desproporción entre las faltas imputables a un migrante y las sanciones imponibles, y la carencia de recursos eficaces contra las medidas que implican la expulsión que integren la ponderación de sus derechos en el control migratorio, redundan en la carencia de un debido proceso como antecedente legitimador tanto de la sanción que se impone al extranjero infractor, como de la denegación a la entrada o de la autorización o renovación de su permiso de residencia.

\section{B. Derecho de los migrantes a la libertad Personal}

El artículo 19 número 7 de la Constitución Política de la República consagra el derecho a la libertad personal y a la seguridad individual, listando el derecho a residir en cualquier lugar de la República, la libre circulación dentro del país y a salir y entrar en él, como sus manifestaciones, siempre que su ejercicio se realice dentro de los límites legales y sin perjuicio de terceros.

El derecho internacional además de prohibir la privación arbitraria y acorde a la ley de este derecho ${ }^{65}$, precisa su dimensión respecto de la detención migratoria.

De este modo, la detención migratoria debe ser excepcional, el último recurso del que se dispone cuando ninguna medida menos restrictiva esté disponible en el caso concreto ${ }^{66}$.

Es así como la Corte Interamericana exige que los Estados cuenten con un catálogo de medidas alternativas a la detención ${ }^{67}$ y considera arbitraria la detención automática como resultado de la presencia irregular de un inmigrante ${ }^{68}$. Asimismo, el Comité de De-

64 Oficina Especializada de Derechos Humanos de la Corporación de Asistencia Judicial (2013): "Solicitud al Pleno de la Corte Supma. por grave situación que afecta a los extranjeros en Chile” en Centro DemoCracia y Comunidad Ciudadano Global et al. (2013) p. 77.

65 Artículo 9 PIDCP, artículo 6 CADH. Reiterado por el Artículo 16 de la CIDTMYF. Ver A. v. Australia (1997) párr. 9.3 que establece que el Estado debe entregar más que razones generales para justificar una detención, pues debe demostrar la existencia de razones específicas y que no existían medidas menos intrusivas disponibles. En el mismo sentido ver, Saed Shams and others v. Australia (2007).

66 C. v. Australia (2002); UN Working Group on Arbitrary Detention (2009), párrafos 67 y 82; Council of Europe, Committee of ministers (2009) principio XI.1. En el mismo sentido, Alto Comisionado de Naciones Unidas para los refugiados (1986), párr. B; Comité para la Eliminación de la discriminación RaCial (2004) párr. 17; Yvon Neptune v. Haití (2008) párr. 90; Álvarez e Iñiguez vs. Ecuador (2007), párr. 53; Vélez Loor vs. Panamá (2010) párrafos 116, 166-171.

67 Vélez Loor vs. Panamá (2010) párr. 169.

68 Vélez Loor vs. Panamá (2010) párr. 166. Así lo ha confirmado también el Comité de Derechos Humanos en A. v. Australia (1997); Madafferi and Madafferi v. Australia (2004) párr. 9.2. 
rechos Humanos autoriza la detención en frontera con fines de identificación, siempre que no se prolongue indebidamente ${ }^{69}$.

Ahora bien, los detenidos por infracciones migratorias no deben ser recluidos en instalaciones penales ${ }^{70} \mathrm{o}$ inadecuadas, incluidas las estaciones de policía ${ }^{71}$, ni deben ser sometidos a torturas o tratamientos crueles, inhumanos o degradantes ${ }^{72}$.

Ciertas protecciones procesales deben observarse respecto de la detención migratoria, como el derecho a ser informado su motivación ${ }^{73}$; el derecho a la asistencia jurídica al momento de la detención y en intervalos regulares ${ }^{74} \mathrm{y}$, cuando sea necesario, a la asesoría jurídica gratuita ${ }^{75}$. Además, el detenido tiene derecho a recurrir judicialmente la legalidad de la detención ${ }^{76}$, tanto en el comienzo como mientras continúe la medida ${ }^{77}$.

La regulación migratoria nacional conculca parcial o totalmente el derecho a la libertad personal de los extranjeros infractores sin observar la mayoría de las exigencias recogidas por el derecho internacional.

Es así como el artículo 82 del Decreto Ley de Extranjería faculta a la autoridad policial a imponer, respecto del extranjero que sea sorprendido contraviniendo la regulación de extranjería, las medidas de retiro de sus documentos de identidad, señalamiento de una localidad de permanencia obligada y la obligación de comparecencia periódica.

Ello, sin que ningún análisis de la proporcionalidad sea realizado por un juez imparcial que considere la gravedad de la falta y las circunstancias particulares del caso. Además, esta medida produce un efecto de apátrida de facto respecto del extranjero concernido, quien al no portar documentos de identidad no podrá ejercer sus derechos mínimos ni demostrar su identidad en el evento de un control policial ulterior.

Adicionalmente, el incumplimiento de cualquiera de estas medidas es causal de expulsión, bastando la constatación policial debidamente informada al Ministerio del Interior. Esta medida no está sujeta a revisión judicial.

\footnotetext{
69 Bakhtiyari v. Australia (2003) párrafos 9.2 - 9.3.

70 Comisión Interamericana de Derechos Humanos (2008).

71 Artículos 7 y 10.1 PIDCP; Artículo 5 CADH. Ver también, Instituto de reducación del menor vs. Paraguay (2004) párrafos 143, 160-162. Ver también, Theo VAN Boven (2003) párr. 49. Para estándares más detallados sobre las condiciones de detención, ver Asamblea General de Naciones Unidas (1988).

72 Artículos 16 CAT; 7 PIDCP; 5 CADH, 9, 10 y 17 de la CIDTMYF.

73 Yvon Neptune v. Haití (2008) párr. 105; Humberto Sánchez vs. Honduras (2003) párrafos 82, 116 y 180.

74 Ver Asamblea General de Naciones Unidas (2000a), párr. 526; UN Working Group on Arbitrary Detention (1998) párr. 69; UN Working Group on Arbitrary Detention (1999) principio 2; Council of Europe, Committee of ministers (2009) directrices XI.5 y 6; Alto Comisionado de Naciones Unidas para los REFUGIADOS (1986).

75 Vélez Loor vs. Panamá (2010) párrafos. 132-133, 146.

76 Artículo 9.4 PIDCP, el artículo 7.6 de la CADH. Ver Neira Alegría y otros vs. Perú (1995) párr. 82; La Cantuta vs. Perú (2006); Hermanas Serrano Cruz vs. El Salvador (2005) párr. 79. Ver también, Corte InTerameriCANA DE DERECHOS HUMANOS (1987) párr. 35.

77 Vélez Loor vs. Panamá (2010) párrafos 107-109, 124, 142-143; A. v. Australia (1997); Suárez-Rosero vs. Ecuador (1997): párr. 63; Mansour Ahani v. Canada (2004).
} 
En el caso en que la expulsión sea decretada por Decreto Supremo del Ministerio del Interior, la detención es una medida automática, pues constituye un requisito de facto para el ejercicio del derecho al recurso de reclamación ${ }^{78}$.

No resulta clara la necesidad de privar al extranjero de libertad, sobre todo porque este ya está sujeto a las medidas limitativas de libertad ya mencionadas y no se prevé la consideración de las circunstancias individuales del afectado, tal como exige el derecho internacional. Se está, más bien, frente a una detención automática de las explícitamente prohibidas por la Corte Interamericana ${ }^{79}$, sobre todo considerando que la decisión de expulsión no es final y está sujeta precisamente a la decisión sobre el recurso de reclamación.

Además, esta detención no está sujeta a ningún control jurisdiccional. Si bien, la legislación nacional concede a los juzgados de garantía el control de la detención, estos juzgados se han declarado incompetentes argumentando que el extranjero no tiene la calidad de imputado según se define en el artículo 7 del Código Procesal Penal ${ }^{80}$. No obstante, el artículo 95 de dicho cuerpo legal no limita el control de la detención a quienes tengan la calidad de imputados, sino que hace referencia a "toda persona privada de libertad" lo que justificaría la acción de estos tribunales respeto de las detenciones migratorias ${ }^{81}$. En cualquier caso, las Cortes de Apelaciones siguen siendo competentes para conocer acciones de amparo respecto de estas detenciones.

Por lo demás, la regulación de extranjería nacional no establece la duración máxima de la detención migratoria ni mecanismo alguno de control periódico de esta medida. Tampoco se han creado instalaciones adecuadas para llevar a cabo esta detención.

Así las cosas, el derecho a la libertad personal de las personas extranjeras en virtud de la normativa migratoria nacional está visiblemente menos protegido que aquel de los nacionales y extranjeros en el marco del sistema penal. El Decreto Ley de Extranjería y su Reglamento, presionan la balanza en franco favor del control migratorio a expensas de las garantías mínimas establecidas por el derecho internacional y de las que las personas migrantes son titulares.

\section{Derechos SOCIALES DE los Migrantes}

Como la regulación de extranjería no se pronuncia sobre los derechos sociales de los extranjeros, los extranjeros tienen acceso a los derechos sociales en las mismas condiciones que los nacionales, de acuerdo a la regulación constitucional.

\footnotetext{
78 Artículo 89 del Decreto Ley de Extranjería.

79 Vélez Loor vs. Panamá (2010) párr. 166.

80 Oficina Especializada de Derechos Humanos de la Corporación de Asistencia Judicial (2013): "Solicitud al Pleno de la Corte Supma. por grave situación que afecta a los extranjeros en Chile" en Centro DemoCracia y Comunidad Ciudadano Global et al. (2013). Un Chile Abierto: Propuestas para una nueva ley de migración, No. 2, Chile 2013, disponible en http://incami.cl/wp-content/uploads/2013/08/Un_Chile_Abierto. pdf. (2013), p. 67

81 Oficina Especializada de Derechos Humanos de la Corporación de Asistencia Judicial (2013): "Solicitud al Pleno de la Corte Supma. por grave situación que afecta a los extranjeros en Chile" en Centro DemoCracia y Comunidad Ciudadano Global ET AL. (2013). Un Chile Abierto: Propuestas para una nueva ley de migración, No. 2, Chile 2013, disponible en http://incami.cl/wp-content/uploads/2013/08/Un_Chile_Abierto. pdf. (2013), p. p. 76.
} 
No obstante, la práctica de los órganos públicos exige la presentación del carné de identidad como condición para el ejercicio de muchos de los derechos sociales, lo que se traduce en una denegación de facto de los derechos mínimos de los extranjeros en calidad de turistas, con sus permisos en trámite o en situación administrativa irregular ${ }^{82}$.

Esta denegación se encuentra en contradicción con las obligaciones constitucionales e internacionales jurídicamente vinculantes para Chile que establecen ciertos derechos sociales mínimos, como la salud y la educación.

Para conformarse con sus obligaciones, Chile optó por creación de convenios de colaboración y acción conjunta entre el Ministerio del Interior y los Servicios o Ministerios encargados de la prestación de servicios educacionales o de salud. Esta solución restringe la efectividad de estos derechos, pues no establece formas de reclamación de los mismos, lo que muchas veces se traduce en su inexistencia práctica ${ }^{83}$.

\section{i. Derecho a la educación}

El derecho a la educación se encuentra recogido en el artículo 19 número 10 de la Constitución Política de la República, precisándose que el Estado debe promover la educación parvularia gratuita y asegurar el acceso gratuito de toda la población a la educación básica y media.

El derecho internacional garantiza también el derecho a la educación pública -tanto en el artículo 28.1 de la Convención de los Derechos del Niño como en el artículo 30 de la Convención Internacional sobre los Derechos de todos los trabajadores migratorios y sus familiares- a todas las personas en edad de asistir a la escuela, independientemente de su situación administrativa ${ }^{84}$.

Como la regulación de extranjería no norma este derecho, una serie de instrumentos han venido a suplir la laguna. De esta forma, al Decreto Supremo 651 de 28 de noviembre de $1995^{85}$ se han sumado el Convenio de Colaboración y Acción conjunta entre el Ministerio del Interior y la Junta Nacional de Jardines Infantiles (“JUNJI") ${ }^{86}$ y los Oficios Circulares 1179 de 2003 y 1531 de $2005^{87}$.

\footnotetext{
82 Ciertos derechos sociales presentan diferencias en el acceso en perjuicio de la población inmigrante. Este es el caso del acceso a los subsidios para la compra y construcción de vivienda urbana y rural, que se otorgan según el puntaje obtenido con base a la situación de vulnerabilidad del demandante, pero en el caso de los extranjeros se exige la titularidad de un permiso de residencia definitiva. Ciudadano global (2013): "Reflexiones de un deber ser. Hacia la primera ley migratoria en la sociedad Chilena” en Centro Democracia y Comunidad Ciudadano Global ET AL. (2013). Un Chile Abierto: Propuestas para una nueva ley de migración, No. 2, Chile 2013, disponible en http://incami.cl/wp-content/uploads/2013/08/Un_Chile_Abierto.pdf. (2013) p. 31

83 Ibíd., p. 26

84 Ver, Comité sobre los derechos económicos, sociales y Culturales (1999) párrafos 6 (b), 34 y 31.

85 D.S. 651 del 28 de noviembre de 1995, aprueba procedimientos para el reconocimiento de estudios de enseñanza básica y de enseñanza media humanístico-científico y técnico profesional.

86 Aprobado por Resolución Exenta 6677, Santiago 20 de noviembre 2007.

87 Oficio Circular 07/1008 (1531) 4 agosto 2005; Oficio Circular 1179 de 2003, del Departamento de Extranjería y Migración, del Ministerio del Interior. Instruye sobre el Ingreso, permanencia y ejercicio de los derechos de los alumnos (as) inmigrantes en los establecimientos educacionales que cuentan con el reconocimiento oficial.
} 
El Convenio entre el Ministerio del Interior y la JUNJI facilita el ingreso a los programas de educación preescolar a los niños y niñas inmigrantes, independientemente de su estatus migratorio. La inscripción en alguno de los establecimientos de la red parvularia dependiente de JUNJI permite la regularización de los niños y niñas indocumentados.

De forma complementaria, los oficios circulares 1179 de 2003 y 1531 de 2005, facilitan el ingreso de los estudiantes inmigrantes que cuenten con la autorización otorgada por el respectivo Departamento Provincial de Educación y un documento que acredite su identidad y edad.

Esta autorización se otorga a todo estudiante que acompañe la documentación acreditativa de los últimos estudios cursados en el país de origen, empero, solo da lugar a una matrícula provisoria, que pasa a ser definitiva solo si el extranjero obtiene un permiso de residencia como estudiante titular antes de las evaluaciones de fin de año.

De esta forma, aunque estos instrumentos buscan la integración de los niños y niñas inmigrantes en el sistema escolar, su estructura funciona como una forma de exclusión, pues si al final del año el estudiante no ha normalizado su documentación, sus notas no ingresan al sistema del Ministerio de Educación ni es promovido de curso ${ }^{88}$.

Vincular la promoción del año escolar con la regularidad administrativa conculca su derecho mínimo a la educación y no parece tener más fundamento que el control migratorio del estudiante o de sus padres o tutores. Menos aún si se considera que dicha regularidad administrativa depende de factores ajenos a su voluntad, como la falta de celeridad del sistema de tramitación o la diligencia de sus representantes legales.

\section{ii. Derecho a la salud}

El derecho a la salud se encuentra recogido por el artículo 19 número 9 de la Constitución Política de la República.

El derecho internacional ha especificado la dimensión del derecho mínimo a la salud del que son beneficiarias las personas migrantes. Es así como la Convención de los Derechos del Niño establece en su artículo 24.1 el derecho del niño "del disfrute del más alto posible nivel de salud", precisando en su número $2 \mathrm{~b}$ ) el deber del Estado de asegurar la prestación de la asistencia médica y sanitaria necesaria. De la misma forma, este tratado consagra el deber del Estado a prestar atención de preparto y postparto en el artículo 24.2 b). Por último, el artículo 28 de la Convención Internacional sobre los Derechos de todos los Trabajadores Migratorios y sus Familiares consagra el derecho a la atención sanitaria de urgencia ${ }^{89}$.

El Estado de Chile ha intentado conformar su regulación nacional a los derechos mínimos de atención de salud, a través de instrumentos de rango infralegal.

La atención médica de urgencia para los extranjeros indocumentados está dispuesta por el Oficio ordinario A-14 No 3229 de 11 junio 2008.

88 Instituto Nacional de Derechos Humanos (2011) p. 209.

89 Este derecho, así como el derecho a recibir atención primaria es reiterado por el Comité de derechos económicos, sociales y culturales. Ver COMité sobre los derechos eCONÓmicos, sociales y CUlturales (2007) párr. 37. 
Por su parte, la Resolución 512 de 30 de noviembre de 2007 y la Resolución Exenta 1914 de 10 de marzo de 2008, proporcionan a todos los niños, niñas y adolescentes extranjeros menores de 18 años la atención de salud en los establecimientos de la red pública. Para hacer efectivo este derecho, los niños, niñas y adolescentes en situación administrativa irregular deben ser inscritos en el establecimiento de atención primaria correspondiente a su domicilio. Esta inscripción o un certificado de atención en algún centro de salud pública conferido por el médico tratante, les permiten solicitar un permiso de residencia temporaria, si estos no asisten a un establecimiento educacional.

Por último, la protección de la maternidad se establece en tres instrumentos ${ }^{90}$ que reconocen el derecho de las mujeres en estado de gravidez a ser controladas por un médico y a obtener -bajo la presentación de un certificado de control de embarazo- una visación de residencia temporaria. Eso sí, se excluye de esta protección a las mujeres que han ingresado clandestinamente al país ${ }^{91}$.

Dado que el derecho a la asistencia sanitaria en la gravidez no admite este tipo de distinciones, nuevamente la protección de este derecho mínimo cede a los objetivos del control migratorio, sancionando la entrada clandestina con la denegación de la protección de salud.

\section{iii. Interferencia de las facultades de control migratorio en el ejercicio de los derechos sociales minimos}

Como se señalara, el sistema de protección social exige la presentación de una cédula de identidad vigente al momento de solicitar una prestación, sea educacional o de salud.

Dicha exigencia dificulta el ejercicio de los derechos mínimos, en especial en materia sanitaria, pues la urgencia de la prestación hace imposible la obtención previa de tal documento.

Esta situación se agrava por la desinformación presente entre los funcionarios públicos, quienes desconocen la existencia de estas normas y no son fiscalizados en su aplicación ${ }^{92}$, lo que se traduce en la demora en la atención u admisión, denegando de facto los derechos mínimos de los inmigrantes.

Adicionalmente, la demora en la atención médica en la gravidez ha propiciado que la regularización de la situación administrativa de las madres se realice después del parto, poniendo en riesgo el acceso a la nacionalidad chilena por parte del hijo. Ello, pues el Registro Civil ha sostenido una práctica -contraria al derecho constitucional- de inscribir como hijos de extranjeros transeúntes a los hijos de los inmigrantes indocumentados ${ }^{93}$.

\footnotetext{
90 Oficio Circular 1179 del 28 de enero de 2003 complementado por el Oficio Circular 6232 de 26 de mayo de 2003 y el Oficio Ordinario-A-14 3229 de 11 de junio 2008.

91 Punto 4.1 Oficio Ordinario-A-14 3229 de 11 de junio 2008

92 En su informe, el Comité de Protección de los Derechos de los Trabajadores Migratorios y de sus Familiares denuncia la insuficiente aplicación de los oficios ordinarios en materia de salud, así como el desconocimiento del personal respecto de los derechos de los trabajadores migratorios y recomienda al Estado de Chile que tome las medidas necesarias para su aplicación eficaz. Ver, Libertades Públicas A.G. (2013): "Niños inmigrantes y derechos sociales". Crítica a la legislación chilena actual, en Centro Democracia y Comunidad Ciudadano Global et al. (2013) p. 100.

93 Esta práctica ha sido condenada por el Dictamen 6197, del 17 de febrero de 1998 de la Contraloría General de la República y la Sentencia de la Corte Suprema en el caso Nestares Alcántara, Helvi con Departamento de Extranjería y Migración del Ministerio del Interior y otro (2009).
} 
Otras contradicciones se producen a causa de ciertas facultades de control migratorio respecto del ejercicio de estos derechos.

Si bien, la competencia primordial para realizar el control migratorio tanto en frontera como en territorio pertenece a la Policía de Investigaciones ${ }^{94}$, muchas competencias de control han sido conferidas al resto de funcionarios públicos, e inclusive, a particulares.

El control de identidad de los extranjeros en territorio nacional ${ }^{95}$ puede realizarse en cualquier momento, sin que medie motivo alguno. Ello, difiere del control que se prevé en el artículo 85 del Código Procesal Penal, que exige que se realice cuando haya indicios de la comisión de una infracción penal, de la existencia de informaciones útiles relativas a una infracción penal o cuando se disimular la identidad de alguna forma.

Dada la diferencia esencial entre los dos tipos de control, es preciso cuestionar la manera en que la Policía de Investigaciones distinguirá la población extranjera de la nacional, con el fin de ejercer sus facultades. Pareciera que la regulación de extranjería incitara a la utilización del perfil racial como herramienta de distinción, lo que se encuentra en contradicción con el principio de igualdad y no discriminación.

Una obligación de control migratorio pesa también sobre el resto de los funcionarios públicos $^{96}$, quienes deben comprobar la residencia legal de los extranjeros que tramiten asuntos de su competencia.

Esta norma tiene un natural efecto disuasorio respecto de los inmigrantes que ejercitan sus derechos mínimos, pues el ejercicio de un derecho a la prestación de salud de urgencia, por ejemplo, conllevará la incoación de un procedimiento sancionatorio en su contra. De la misma manera, el permiso de estudiante titular debe ser solicitado por el representante legal del estudiante, lo que implicaría su control migratorio. Ello, pone a los padres frente a una decisión imposible, pues o bien cumplen con el deber de escolarización de sus hijos poniendo en riesgo su permanencia en el país, o bien incumplen dicho deber para proteger la estabilidad de su estancia en territorio nacional.

Además, las empresas de transporte nacional e internacional ${ }^{197}$, los propietarios, administradores, gerentes o encargados de hoteles, residenciales o casas de hospedaje y los propietarios o arrendadores que arrienden a extranjeros ${ }^{98}$ también son obligados a comprobar la residencia legal de quienes les contraten.

Por último, la regulación de extranjería obliga a controlar la situación migratoria a los particulares que dieren alojamiento a extranjeros a título gratuito ${ }^{99}$. Otra vez, cabe pre-

94 Artículo 10 del Decreto Ley de Extranjería y 4 de su Reglamento consagran el control fronterizo y autorizan también a Carabineros de Chile a actuar en ausencia de la Policía de Investigaciones o en los casos en que el Ministerio del Interior establezca una labor conjunta. La autoridad marítima realiza este control en los puestos de mar.

95 Artículo 5 inciso 1 del Reglamento de Extranjería.

96 Artículo 76 del Decreto Ley de Extranjería y 155 de su Reglamento

97 Artículos 11 y 12 del Decreto Ley de Extranjería, artículos 18 al 25 del Reglamento de Extranjería, respecto de las empresas de transporte internacional y el artículo 73 del Decreto Ley de Extranjería y los artículos 150 y 151 del Reglamento de Extranjería, respecto de las empresas de transporte nacional.

98 Artículo 77 del Decreto Ley de Extranjería y el artículo 156 del Reglamento de Extranjería.

99 Artículo 156 inciso 2 del Reglamento de Extranjería. 
guntarse cuál es el criterio que permitirá al particular distinguir a sus invitados extranjeros, en especial, cuando algunos de ellos pueden haber nacido en Chile.

Adicionalmente, la descentralización del control migratorio, tanto en particulares como en funcionarios públicos no especializados reviste ciertas dificultades técnicas. Ello, porque la normativa migratoria admite la caducidad ipso iure de los permisos sujetos a contrato cuando la relación laboral termina y no establece plazos máximos de tramitación de sus autorizaciones. Estos elementos implican la inexactitud de todo control no especializado, pues el porte de un carné de identidad vigente no es necesariamente garantía de una situación migratoria regular y a la inversa, la expiración de dicho documento o su ausencia, no implica la irregularidad migratoria. Si bien, se listan documentos acreditativos distintos al carné en el artículo 157 del Decreto Ley de Extranjería, su correcta aplicación exige un conocimiento jurídico especializado.

Esta diversificación en el control implica la denegación de facto de los derechos sociales mínimos de los inmigrantes, a la vez que no sirve a un control migratorio eficaz. Todo ello, produciendo el efecto colateral del establecimiento de un manto de sospecha respecto de la población inmigrante, dificultando su inclusión social y poniendo en peligro la convivencia nacional.

\section{Derechos laborales de los trabajadores migratorios}

El artículo 19 número 16 de la Constitución Política de la República regula la libertad de trabajo y su protección y prohíbe la discriminación en materia laboral ${ }^{100}$.

La Convención sobre los derechos de todos los trabajadores migratorios y sus familiares prohíbe la esclavitud y el trabajo forzado, reitera el derecho a la igualdad de trato de los trabajadores extranjeros respecto de los nacionales en lo que se refiere a las condiciones laborales y de paga, el derecho a la sindicación y a la seguridad social ${ }^{101}$.

Pese a que el artículo 2 del Código del Trabajo reitera la prohibición de discriminación entre trabajadores nacionales y extranjeros ${ }^{102}$, la regulación migratoria admite distinciones respecto de los trabajadores inmigrantes que se traducen en diferencias significativas en la protección de sus derechos laborales. Considerando la permanente necesidad de mano de obra extranjera presente en el sistema productivo nacional, estas diferencias implican la precarización del trabajo inmigrante que pasa a formar parte de la economía sumergida, además de una marcada desproporción del poder del empleador respeto del trabajador, tanto en el mercado laboral formal como informal.

De acuerdo a la regulación de extranjería nacional, los contratos de trabajo en que el trabajador es un inmigrante deben firmarse ante notario o funcionario consular, dependiendo del lugar de la firma; la profesión, actividad o trabajo contratado debe ser indis-

\footnotetext{
100 Empero, ciertas profesiones exigen la nacionalidad chilena. Este es el caso de los porteros, vigilantes privados, nocheros y rondines de acuerdo al D.S. 93 de 1985, el D.S. 1173 de 1994 y Decreto Ley 3607 de 1981.

101 Artículos 11, 25 al 27 de la CIDTMYF.

102 Los artículos 19 y 20 del Código del Trabajo exigen que las empresas de más de 28 trabajadores a nivel nacional tengan un $85 \%$ de trabajadores chilenos, pero numerosas excepciones matizan esta exigencia.
} 
pensable o necesario y la actividad no debe ser considerada un peligro o atentado para la seguridad nacional ${ }^{103}$.

Además, se exige la introducción de dos cláusulas especiales: la cláusula viaje ${ }^{104}$ en la que el empleador se compromete a pagar el viaje de regreso al trabajador y su familia y la cláusula referente al régimen previsional ${ }^{105}$.

La cláusula viaje no se ajusta a una política migratoria que reconozca el valor de la migración en el plano económico. Ello, porque la mano de obra inmigrante hace posible el desarrollo de la economía nacional que no está suficientemente abastecida por la mano de obra interna, lo que se refleja en tasas de desempleo bajas, pese a una creciente migración.

Trasladar el costo económico del retorno al empleador desconoce el rol del Estado respecto de la gestión de la inmigración. Es el Estado quien debe asegurar un correcto suministro de fuerza de trabajo que permita el bienestar de la sociedad, para lo que debe promover la circulación de la mano de obra inmigrante, la regularización de su situación administrativa y la gestión de su retorno, en caso de ser necesario.

Imponer trabas económicas a la contratación de trabajadores inmigrantes perjudica las condiciones globales de contratación, pues promueve la entrada de extranjeros en el mercado informal donde reciben peores sueldos en peores condiciones de trabajo.

Adicionalmente, el Decreto Ley de Extranjería establece la falsedad documental como causal de expulsión, lo que frecuentemente se produce a causa de la calificación de contrato falso ${ }^{106}$. Dicha calificación, que se funda regularmente en la ausencia de cotizaciones previsionales, se realiza por un funcionario de la Policía de Investigaciones e invalida tanto la relación laboral como los derechos que emanan de esta.

Estas normas contradicen la normativa laboral nacional, pues tanto el Código del Trabajo como el Código Civil consideran el contrato de trabajo como uno de naturaleza consensual, por lo que es válido sin escrituración ni la realización de las cotizaciones previsionales, siempre que pueda probarse la relación de subordinación y dependencia. Además, ninguno de esos cuerpos normativos habilita a un funcionario de la policía a calificar el fondo o la veracidad del contrato, por lo que en sus calificaciones de contrato falso constituyen la arrogación de facultades propias del poder judicial.

Adicionalmente, el artículo 25 Decreto Ley de Extranjería establece la caducidad ipso iure de la visación sujeta a contrato por el término de la relación laboral. Esta normativa, no solo es perniciosa para trabajador inmigrante -quien queda en situación administrativa irregular en el plazo de un mes si pierde su trabajo y no consigue otro o está excesivamente a merced de su empleador, si quiere conservarlo- sino que es perniciosa para el mercado laboral en su conjunto, pues le resta la flexibilidad necesaria a la mano de obra para colocarse donde sea más productiva.

\footnotetext{
103 Artículo 36 del Decreto Ley de Extranjería.

104 Artículo 24 del Decreto Ley de Extranjería y 37 del Reglamento de Extranjería.

105 Torres Escudero (2011). Esta cláusula sería innecesaria si se permitiera al trabajador retirar sus cotizaciones en el momento de regresar a su país de origen.

106 Artículo 75 del Decreto Ley de Extranjería.
} 
Por lo demás, la ley desincentiva la notificación del cambio de empleador por parte del trabajador migrante, pues condiciona su admisión a una posible sanción pecuniaria difícil de pagar por parte de un trabajador que ha perdido su trabajo.

En definitiva, las normas especiales que se aplican al contrato laboral de los trabajadores migratorios y a su autorización de residencia violan los derechos mínimos de los trabajadores indocumentados, pues crean un régimen laboral de excepción, menos garantista y suficientemente flexible para negar los derechos del trabajador inmigrante gracias al desconocimiento del contrato laboral y promueven la irregularidad administrativa de estos trabajadores, al vincular el permiso de trabajo con un empleador específico.

\section{CONCLUSIÓN}

Como se traduce del análisis precedentemente expuesto, aunque Chile integra de iure muchos de los derechos mínimos de los que son titulares los inmigrantes, independientemente de su estatus migratorio, los mecanismos de control migratorio establecidos en su normativa de extranjería contradicen de facto l'effet utile de dichos derechos mínimos.

Ello, a causa de la marcada indefinición de los términos en los que se prevé dicho control, del amplio margen de discreción con el que cuentan los funcionarios llamados a aplicar estos dispositivos de control migratorio, así como la falta de control judicial de las actuaciones que se realizan en este marco.

No obstante, estos mecanismos de control soberano no parecen servir ni a sus propios fines. La ausencia de una política migratoria que busque algo más que la expulsión masiva, traduce estas facultades de control en arbitrariedad administrativa y discriminación. Además, la falta de especialización en materia migratoria de los funcionarios públicos y particulares a quienes se exige el ejercicio de facultades de control migratorio supone no solamente un tratamiento discriminatorio y de sospecha respecto de los extranjeros, sino que la realización de un control migratorio erróneo.

Por último, los derechos laborales de los inmigrantes se ven permanentemente amenazados por las exigencias especiales que se exigen en la contratación de trabajadores extranjeros. Estas distinciones son de tal entidad, que suponen la creación de una segunda clase de trabajadores, así como una amenaza para el sistema productivo.

La manera óptima de coordinar el control migratorio con la garantía de los derechos mínimos de los inmigrantes implicaría la reforma completa de la regulación de extranjería con el fin de actualizar sus normas consagrando expresamente los derechos mínimos de los inmigrantes, consolidando el mismo tratamiento jurídico respecto de los nacionales y centralizando el control migratorio en la Policía de Investigaciones. El debido ejercicio de los derechos de los inmigrantes indocumentados no puede ser armonizado con un control migratorio descentralizado y delegado que se efectúe en el mismo momento en que se solicita una prestación social jurídicamente protegida o se ejerza el derecho al recurso.

Aunque el Proyecto de Ley introducido por Mensaje No 89-361 de 20 de mayo de 2013 busca actualizar la normativa migratoria chilena, este esfuerzo es insuficiente.

Ello, porque consagra una cantidad limitada de derechos en favor de los extranjeros, sin reconocer la totalidad de los derechos que les corresponden conformemente a la Consti- 
tución chilena y los tratados internacionales ratificados por Chile. Además, el proyecto deja en manos del legislador reglamentario los aspectos procedimentales de estos derechos, por lo que no es posible afirmar que los problemas ligados a la exigencia de la cédula nacional de identidad no persistirán respecto de los extranjeros que solo cuentan con pasaporte.

Asimismo, el proyecto mantiene una estructura de control migratorio descentralizada y delegada. De hecho, los transportistas, empleadores y universidades son obligados a realizar controles migratorios que van más allá de la revisión del documento de identidad. Finalmente, las hipótesis que permiten una revocación o rechazo de un permiso de residencia mantienen su tenor, manteniendo las facultades de control migratorio discrecionales ya criticadas.

Un equilibrio correcto entre las dos vertientes del derecho migratorio debe incorporar completamente las exigencias del derecho internacional respecto de la protección de los derechos humanos mínimos de los inmigrantes a la vez que fiscalizar el estatus migratorio de los extranjeros a través de controles generalizados de la población realizados únicamente por la Policía de Investigaciones. Ello permitiría la erradicación del empleo de técnicas de perfil racial, que no hacen más que reforzar y perpetuar estereotipos y prejuicios respecto de la población inmigrante, dificultando su inclusión social y agravando la situación de vulnerabilidad en la que se encuentra.

\section{BIBLIOGRAFÍA CITADA}

Alto Comisionado de Naciones Unidas para los Refugiados (1986): "Detention of Refugees and Asylum-Seekers", disponible en http://www.refworld.ord/docid/3ae68c43c0. html.

Asamblea General de Naciones Unidas (1988): "Resolución 43/173, Body of Principles for the Protection of All Persons under Any Form of Detention or Imprisonment", disponible en http://www.un.org/documents/ga/res/43/a43r173.htm.

Asamblea General de Naciones Unidas (2000a): "Informe de Derechos Humanos", Vol.I, disponible en http://www.ccprcentre.org/wp-content/uploads/2012/09/A.66.40_ Vol.I_S.pdf.

Asamblea General de Naciones Unidas (2000b): "Resolución A/RES/54/166, Protección de los migrantes", disponible en https:/www.iom.int/jahia/webdav/shared/shared/mainsite/policy_and_research/un/55/A_RES_55_92_es.pdf.

Centro Democracia y Comunidad Ciudadano Global, Organización Internacional del Trabajo, Oficina especializada de Derechos Humanos de la Corporación de Asistencia judicial, Instituto Católico Chileno de Migración, Libertades Públicas A.G. (2013): "Un Chile Abierto: Propuestas para una nueva ley de migración", No. 2, Chile 2013, disponible en http://incami.cl/wp-content/uploads/2013/08/Un_Chile_Abierto.pdf.

Comisión Interamericana de Derechos Humanos (2002): "Informe sobre Terrorismo y Derechos Humanos", disponible en https://www.oas.org/dil/esp/informe_sobre_terrorismo_derechos_humanos.pdf. 
Comisión Interamericana de Derechos Humanos (2008): "Resolución 03/08. Derechos humanos de los migrantes, Estándares Internacionales y Directiva Europea sobre Retorno", disponible en https:/www.cidh.oas.org/Resoluciones/Resolucion.03.08.ESP.pdf.

Comisión Interamericana de Derechos Humanos (2008): "Resolución 03/08. Derechos humanos de los migrantes, Estándares Internacionales y Directiva Europea sobre Retorno", disponible en https://www.cidh.oas.org/Resoluciones/Resolucion.03.08.ESP.pdf.

Comité de Derechos Humanos (1986): “Observación general No. 15 sobre la situación de los extranjeros con arreglo al Pacto", disponible en http://www1.umn.edu/humanrts/ hrcommittee/Sgencom 15. html

Comité de Derechos Humanos (1999): “Observación General No. 27, sobre la libertad de circulación”, disponible en http://www1.umn.edu/humanrts/hrcommittee/Sgencom27.html

Comité de Derechos Humanos (2001): "Observaciones finales sobre el cuarto informe periódico sobre Nueva Zelanda”, disponible en, http://docstore.ohchr.org/SelfServices/ FilesHandler.ashx?enc=6QkG1d\%2fPPRiCAqhKb7yhstky1HJJMM0R\%2bg124Xadhh 7usfSISdZt2ApnjqsTLjWivGPOjeDav2DFoM4bhr3NNp\%2fRk\%2f52FVDLOa0pTzr aArh8PCFy2zGdoKx\%2b6lQgomgt

Comité de Derechos Humanos (2004): "Observación General No. 31, Naturaleza de la obligación jurídica general impuesta a los Estados Partes en el Pacto", disponible en http://www.refworld.org/cgi-bin/texis/vtx/rwmain/opendocpdf. pdf?reldoc $=y \&$ docid $=478$ b26ea 2

COMité PARA la Eliminación de la discriminación Racial (2004): “Observaciones finales del Comité sobre las Bahamas”, disponible en http://docstore.ohchr.org/SelfServices/ FilesHandler.ashx?enc=6QkG1d\%2fPPRiCAqhKb7yhsohLRIU9d15RhG\%2bIHTPFU 4sJ\%2fN\%2bf\%2fC\%2bQ5wwX2a8R9DNt4bk9rkn\%2b2c4gbDZ1HpIPWxGWMoh J\%2b8IeprAbPptW\%2bzqVuKdzk42O2b2JYMJOjkcB

Comité sobre los derechos eCONÓmicos, sociales y Culturales (1999): "Comentario General No. 13 sobre el derecho a la educación”, disponible en http://www1.umn.edu/ humanrts/gencomm/epcomm13s.htm

Comité sobre los Derechos eCONÓmicos, sociales y CUlturales (2007): "Comentario General No. 19, sobre derecho a la seguridad social”, disponible en http://www1.umn. edu/humanrts/gencomm/escgencom 19.html

Corte Interamericana de Derechos Humanos (1987): "Habeas Corpus bajo suspensión de garantías (artículos 27.2, 25.1 y 7.6 CADH) (Opinión consultiva OC-8/87)”, disponible en http://www.corteidh.or.cr/docs/opiniones/seriea_08_esp.pdf.

Corte Interamericana de Derechos Humanos (1999): "El derecho a la información sobre la asistencia consular en el marco de las garantías del debido proceso legal (Opinión consultiva Corte ID HOC-16/99)", disponible en http://www.corteidh.or.cr/docs/opiniones/seriea_16_esp.pdf.

Corte Interamericana de Derechos Humanos (2002): "Resolución 2/11 sobre la Situación de los Detenidos de la Bahía de Guantánamo, Estados Unidos, Medidas Cautelares 259-02", disponible en https://www.cidh.oas.org/pdf\%20files/Resoluci\%C3\%B3n\%20 2-11\%20Guant\%C3\%A1 namo.pdf. 
Corte Interamericana de Derechos Humanos (2003): “Condición Jurídica y los derechos de los migrantes indocumentados (Opinión Consultiva OC 18/03)”, disponible en http://www.corteidh.or.cr/docs/opiniones/seriea_18_esp.doc.

Council of Europe, Committee of ministers (2009): “Guidelines on human protection in the context of accelerated asylum procedures", disponible en http://www.refworld. org/docid/4a857e692.html.

Cour Internationale de Justice (2004) : “Conséquences juridiques de l'édification d'un mur dans le territoire palestinien occupé (Avis Consultatif)", disponible en http://www. icj-cij.org/docket/files/131/1671.pdf.

Instituto Nacional de Derechos Humanos (2011): "Informe Anual, Situación de los Derechos Humanos en Chile”, disponible en http://www.indh.cl/wp-content/ uploads/2011/12/27555-Informe-Anual-2011-BAJA1.pdf.

Kamto, Maurice (2007): “Tercer Informe sobre la expulsión de extranjeros", disponible en http://www.refworld.org/cgi-bin/texis/vtx/rwmain/opendocpdf. pdf? reldoc $=y \&$ docid $=4 \mathrm{a} 2 \mathrm{~cd} 2 \mathrm{e} 12$.

Noticias CÁmara de Diputados de Chile, "Este sábado realizan seminario sobre migraciones en congreso nacional en Santiago con testimonios de inmigrantes", 10 de octubre 2014, disponible en http://www.camara.cl/prensa/noticias_detalle.aspx?prmid=118125.

Organización Internacional de Migraciones (2012): Panorama migratorio de América del Sur 2012, disponible en http://www.iom.int/files/live/sites/iom/files/pbn/docs/Panorama_Migratorio_de_America_del_Sur_2012.pdf.

Pérez GonzÁlez, Carmen (2012): Migraciones irregulares y derecho internacional (Valencia, Editorial Tirant lo Blanch, primera edición).

Pérez-Prat Durban, L. (2007): Inmigración y Derecho Internacional: ¿un acuerdo imposible?, en Curso de Derechos Humanos de Donostia-San Sebastián, Vol. VII (Bilbao, Universidad del País Vasco) pp. 137-164.

Rigaux, F. (2000) : Immigration, droit international et droits fondamentaux, en Les droits de l'homme au seuil du troisième millénaire. Mélanges en hommage à Pierre Lambert, (Bruxelles, Editorial Bruylant).

Presidente de la República (2008): “Imparte Instrucciones sobre la Política Nacional Migratoria”, disponible en http://transparenciaactiva.presidencia.cl/Otros\%20Antecedentes/16.-\%20Inst.\%20N\%C2\%BA\%209.pdf.

Torres-Marenco, Verónica (2011): "La migración en el sistema Interamericano de Derechos Humanos", No Vniversita: 122 pp. 41-76.

Torres Escudero, Carmen. (2011): “Guía de apoyo Soy Migrante, Tengo Derechos”, disponible en http://www.insmujer.cl/soymigrante/wp-content/uploads/2011/04/guiaapoyo-soy-migrante-tengo-derechos.pdf.

UN Working Group on Arbitrary Detention: (1998): "Annual Report 1998”, disponible en http://daccess-dds-ny.un.org/doc/UNDOC/GEN/G98/052/52/PDF/G9805252. pdf?OpenElement.

UN Working Group on Arbitrary Detention (1999): “Annual Report 1999”, disponible en http://daccess-dds-ny.un.org/doc/UNDOC/GEN/G99/165/70/PDF/G9916570. pdf?OpenElement. 
UN Working Group on Arbitrary Detention (2009): “Annual Report 2008”, disponible en http://daccess-dds-ny.un.org/doc/UNDOC/GEN/G09/110/43/PDF/G0911043. pdf?OpenElement.

VAn Boven, Theo (2003) "Informe Relator Especial: los Derechos Civiles y Políticos, en particular las cuestiones relacionadas con la tortura y la detención”, disponible en http://daccess-dds-ny.un.org/doc/UNDOC/GEN/G03/173/30/PDF/G0317330. pdf?OpenElement.

\section{NORMAS CITADAS}

Declaración Universal de Derechos Humanos (1948). Disponible en http://www.un.org/ es/documents/udhr/index.shtml.

Declaración Americana de los derechos y deberes del hombre (1948). Disponible en http:// www.cidh.org/basicos/Basicos1.htm.

Pacto Internacional de Derechos Civiles y Políticos (1963). Disponible en http://www.unhchr.ch/spanish/html/menu3/b/a_ccpr_sp.htm.

Pacto Internacional de Derechos Económicos, Sociales y Culturales (1966). Disponible en http://www.ohchr.org/SP/ProfessionalInterest/Pages/CESCR.aspx.

Convención Americana sobre Derechos Humanos (1969). Disponible en http://www.oas. org/juridico/spanish/Tratados/b-32.html.

Convención contra todas las formas de discriminación contra la mujer (1979). Disponible en http://www.un.org/womenwatch/daw/cedaw/text/sconvention.htm.

Convención contra la tortura y otros tratos o penas crueles inhumanas o degradantes (1984). Disponible en http://www.juridicas.unam.mx/publica/librev/rev/derhum/ cont/37/pr/pr32.pdf.

Convención de los derechos del niño (1990). Disponible en http://www2.ohchr.org/spanish/law/crc.htm.

Convención Internacional sobre la protección de los derechos de todos los trabajadores migratorios y sus familiares (1990), disponible en http://unesdoc.unesco.org/ images/0014/001435/143557s.pdf.

Constitución Política de la República de Chile, cuyo texto refundido, coordinado y sistematizado fue fijado por el Decreto 100, de 2005, del Ministerio Secretaría General de la Presidencia.

Decreto Ley 1094 de 19 de julio de 1975, Normas sobre extranjeros en Chile

Decreto Supremo 597 de 24 de noviembre de 1984, Reglamento de Extranjería.

Decreto Supremo 651 de 28 de noviembre de 1995, aprueba procedimientos para el reconocimiento de estudios de enseñanza básica y de enseñanza media humanístico-científico y técnico profesional.

Ley 17.995, 8 de mayo de 1981.

Ley 19.696, de 29 de septiembre de 2000, Código Procesal Penal.

Ley 19.880 de 29 de mayo de 2003, Normas de Procedimiento Administrativo.

Decreto Fuerza Ley 1 de 16 de enero de 2003, Código del Trabajo. 
Resolución Exenta 6677, de 20 de noviembre 2007, aprueba Convenio de Colaboración y Acción conjunta entre el Ministerio del Interior y la Junta Nacional de Jardines Infantiles.

Resolución Exenta 1914, de 10 de marzo de 2008, aprueba Convenio de Colaboración celebrado entre los Ministerios de Salud y del Interior.

Resolución 512, de 30 de noviembre de 2007, aprueba Convenio de colaboración Ministerio del Interior y Ministerio de Salud.

Oficio Circular 1179, de 28 de enero de 2003, informa la suscripción de acuerdos tendientes a resolver situaciones migratorias de ciudadanos extranjeros que se indican.

Oficio Circular 07/1008 (1531), de 4 agosto de 2005, Instruye sobre el Ingreso, permanencia y ejercicio de los derechos de los alumnos(as) inmigrantes en los establecimientos educacionales

Oficio Ordinario A 14 No 3229 de 11 junio 2008, Atención en salud de población inmigrante en riesgo social y situación de permanencia no regular.

Ley Orgánica 4/2000, de 11 de enero, sobre derechos y libertades de los extranjeros en España y su integración social.

Immigration and Nationality Act de 1952 en el 8 U.S. Code 1158.

\section{JURISPRUDENCIA CITADA}

Comité Haitiano de Derechos Humanos vs. Estados Unidos (1997): Comisión Interamericana de Derechos Humanos, 13 de marzo de 1997 (Informe sobre méritos), disponible en https://www.cidh.oas.org/annualrep/96span/EEUU10675.htm

Víctor Saldaño vs. Argentina (1999): Comisión Interamericana de Derechos Humanos, 11 de marzo de 1999 (Peticiones y casos declarados inadmisibles), disponible en http:// www.cidh.oas.org/annualrep/98span/Inadmisibilidad/Argentina.Salda\%C3\%B1o.htm

Coard y otros vs. Estados Unidos (1999): Comisión Interamericana de Derechos Humanos, 29 de septiembre 1999 (Informe de méritos), disponible en http://www.cidh.org/ annualrep/99span/De\%20Fondo/EstadosUnidos10951.htm

Riebe Star y otros vs. México (1999): Comisión Interamericana de Derechos Humanos, 13 de abril de 1999 (Informe de méritos), disponible en http://www.cidh.org/ annualrep/98span/Fondo/Mexico\%2011.610.htm

Neira Alegría y otros vs. Perú (1995): Corte Interamericana de Derechos Humanos, 19 de enero de 1995 (Sentencia) disponible en http://www.corteidh.or.cr/docs/casos/articulos/ seriec_20_esp.pdf.

Suárez-Rosero vs. Ecuador (1997): Corte Interamericana de Derechos Humanos, 12 de noviembre de 1997 (Sentencia), disponible en http://www.corteidh.or.cr/docs/casos/ articulos/seriec_35_esp.pdf

Cantos vs. Argentina (2002): Corte Interamericana de Derechos Humanos, 28 de noviembre de 2002 (Sentencia), disponible en http://www.corteidh.or.cr/docs/casos/articulos/ seriec_97_esp.pdf

Hilaire, Constantine y Benjamin y otros vs. Trinidad y Tobago (2002): Corte Interamericana de Derechos Humanos, 21 de junio de 2002, (Sentencia), disponible en http://www. corteidh.or.cr/docs/casos/articulos/Seriec_94_esp.pdf 
“Cinco Pensionistas” vs. Perú (2003): Corte Interamericana de Derechos Humanos, 28 de febrero de 2003 (Sentencia), disponible en http://www.corteidh.or.cr/docs/casos/articulos/Seriec_98_esp.pdf

Humberto Sánchez vs. Honduras (2003): Corte Interamericana de Derechos Humanos, 7 de junio de 2003 (Sentencia), disponible en http://www.corteidh.or.cr/docs/casos/articulos/seriec_99_esp.pdf

Instituto de reducación del menor vs. Paraguay (2004): Corte Interamericana de Derechos Humanos, 2 de septiembre de 2004, (Sentencia), disponible en http://www.corteidh. or.cr/docs/casos/articulos/seriec_112_esp.pdf

Hermanas Serrano Cruz vs. El Salvador (2005): Corte Interamericana de Derechos Humanos, 11 de marzo de 2005 (Sentencia), disponible en http://www.corteidh.or.cr/docs/ casos/articulos/seriec_120_esp.pdf

La Cantuta vs. Perú (2006): Corte Interamericana de Derechos Humanos, 29 de noviembre de 2006 (Sentencia), disponible en http://www.corteidh.or.cr/docs/casos/articulos/ seriec_162_esp.pdf

Álvarez e Iñiguez vs. Ecuador (2007): Corte Interamericana de Derechos Humanos, 21 de noviembre de 2007 (Sentencia) disponible en http:/www.corteidh.or.cr/docs/casos/articulos/seriec_189_esp.pdf

Yvon Neptune v. Haití (2008): Corte Interamericana de Derechos Humanos, 6 de mayo de 2008 (Sentencia) disponible en http://www.corteidh.or.cr/docs/casos/articulos/seriec_180_esp1.pdf

Vélez Loor vs. Panamá (2010): Corte Interamericana de Derechos Humanos, 23 de noviembre de 2010 (Sentencia) disponible en http://www.corteidh.or.cr/docs/casos/articulos/seriec_218_esp2.pdf

Delia López Burgos v. Uruguay (1979): Comité de Derechos Humanos, 6 junio de 1979 (Communication No. R 12/52), disponible en http:/wwwl.umn.edu/humanrts/undocs/session36/12-52.htm

Celiberti de Casariego v. Uruguay (1981): Comité de Derechos Humanos, 29 de julio de 1981 (Communication No. 56/1979), disponible en http://www1.umn.edu/humanrts/ undocs/html/56_1979.htm

A. v. Australia (1997): Comité de Derechos Humanos, 30 de abril de 1997 (Communication No. 560/1993) disponible en http://www1.umn.edu/humanrts/undocs/html/ vws560.html

C. v. Australia (2002): Comité de Derechos Humanos, 13 de noviembre de 2002 (Communication No. 900/1999), disponible en http://www1.umn.edu/humanrts/undocs/900-1999.html

Mansour Ahani v. Canada (2004): Comité de Derechos Humanos, 2 de abril de 2004 (Communication No. 1051/2002), disponible en http://www1.umn.edu/humanrts/ undocs/html/1051-2002.html

Bakhtiyari v. Australia (2003): Comité de Derechos Humanos, 6 de noviembre de 2003 (Communication No. 1069/2002) disponible en http://www1.umn.edu/humanrts/undocs/1069-2002.html 
Rubin Byahuranga v. Denmark (2004): Comité de Derechos Humanos, 9 de diciembre de 2004 (Communication No. 1222/2003), disponible en http://wwwl.umn.edu/humanrts/undocs/html/1222-2003.html

Madafferi and Madafferi v. Australia (2004): Comité de Derechos Humanos, 26 de agosto de 2004 (Communication No. 1011/2001), disponible en http://www1.umn.edu/humanrts/undocs/html/1011-2001.html

Saed Shams and others v. Australia (2007): Comité de Derechos Humanos, 11 de septiembre de 2007 (Communication No. 1255/2004), disponible en http://www.ag.gov.au/ RightsAndProtections/HumanRights/DisabilityStandards/Documents/ShamsetalvAustralia-Viewsof1 192007.pdf

Dictamen 6197, del 17 de febrero de 1998 de la Contraloría General de la República.

Nestares Alcántara, Helvi y otro con Departamento de Extranjería y Migración del Ministerio del Interior (2009), Corte Suprema, 28 de diciembre de 2009 (acción de protección), Rol de ingreso 6073-2009. 
